\title{
Pengaruh Kualitas Produk Dan Harga Terhadap Keputusan Pembelian Pada Restoran A\&W Supermall Karawaci
}

\author{
Suhendri \\ Manajemen, universitas Buddhi Dharma, Inonesia, Banten
}

\begin{abstract}
Abstrak
Penelitian ini bertujuan untuk mengetahui seberapa besar pengaruh kualitas produk dan harga terhadap keputusan pembelian. Penelitian ini dilakukan dengan menggunakan metode survey. Populasi dalam penelitian ini adalah konsumen Restoran A\&W (Outlet Supermal Karawaci). Pengambilan sampel dengan jumlah 100 orang responden dilakukan dengan teknik insidental sampling.

Analisis data dilakukan dengan uji hipotesis, uji validitas, uji reabilitas, analisis regresi sederhana dan berganda, analisis korelasi sederhana dan berganda, dan analisis koefesien determinasi $\left(\mathrm{R}^{2}\right)$ dalam mengetahui seberapa besar pengaruh dan signifikansi Kualitas Produk dan Harga Terhadap Keputusan Pembelian di Restoran A\&W serta mengetahui variabel yang mempunyai pengaruh paling dominan. Berdasarkan analisis data yang dilakukan dalam penelitian ini, dapat disimpulkan bahwa variabel (X1) yaitu kualitas produk, berpengaruh positif dan signifikan terhadap variabel $(\mathrm{Y})$ yaitu keputusan pembelian dengan nilai koefiesien sebesar 0,871 (cukup kuat). Variabel (X2) yaitu harga berpengaruh positif dan signifikan terhadap variable $(Y)$ minat beli dengan nilai koefisien sebesar 0,866 , (cukup kuat). Variabel (X1) kualitas produk dan variable (X2) harga berpengaruh positif dan signifikan dengan nilai signifikan keduanya yang cukup kuat.

Dari hasil uji F, model 1 didapat nilai 308,095 dan model 2 didapat nilai 196,270, dimana nilai tersebut lebih besar dari $\mathrm{F}$ tabel sebesar 3,09, maka $\mathrm{H}_{\mathrm{o}}$ ditolak dan $\mathrm{H}_{\mathrm{a}}$ diterima, artinya terdapat hubungan positif antara variabel Kualitas Produk terhadap Keputusan Pembelian. Dari hasil uji $\mathrm{t}$ didapat $\mathrm{t}_{\text {hitung }}$ Kualitas Produk sebesar 5,023 dan thitung harga sebesar 4,597, dimana nilai tersebut lebih besar dari 1,98447, maka $\mathrm{H}_{\mathrm{o}}$ ditolak dan $\mathrm{H}_{\mathrm{a}}$ diterima, artinya terdapat hubungan yang signifikan antara kualitas produk dan harga terhadap keputusan pembelian konsumen.
\end{abstract}

Kata kunci : kualitas produk, harga, keputusan pembelian 
Abstract

This research aims to determine how much influence the quality of products and prices on purchasing decisions. This research was conducted using a survey method. The population in this study were consumers of $A \mathcal{E} W$ Restaurant (Outlet Supermal Karawaci). Sampling with the number of 100 respondents was done by incidental sampling technique.

Data analysis was done by hypothesis testing, validity test, reliability test, simple and multiple regression analysis, simple and multiple correlation analysis, and analysis of determination coefficient $\left(R^{2}\right)$ in knowing how much influence and significance of Product Quality and Price on Purchasing Decisions in $A \mathcal{E} W$ Restaurants and know the variables that have the most dominant influence. Based on the data analysis conducted in this study, it can be concluded that the variable (X1), namely product quality, has a positive and significant effect on the variable (Y), namely the purchasing decision with a coefficient value of 0.871 (strong enough). Variable (X2) namely price has a positive and significant effect on variable (Y) interest in buying with a coefficient of 0.866 (strong enough). Variable (X1) product quality and variable (X2) price have a positive and significant effect with significant value both of which are quite strong.

From the results of the F test, model 1 obtained a value of 308.095 and model 2 obtained a value of 196.270, where the value is greater than F table of 3.09, then Ho is rejected and Ha is accepted, meaning that there is a positive relationship between Product Quality variables to Purchasing Decisions. From the results of the t test obtained thitung Product Quality of 5.023 and tcount of 4.597, where the value is greater than 1.98447, then Ho is rejected and $\mathrm{Ha}$ is accepted, meaning that there is a significant relationship between product quality and prices on consumer purchasing decisions.

Keywords: product quality, price, purchasing decision

\section{PENDAHULUAN}

Melihat kondisi persaingan bisnis restoran saat ini cukup ketat dan semakin meningkat. Setiap Perusahaan dituntut untuk mengerti dan memahami apa yang terjadi di pasar dan apa yang menjadi keinginan konsumen serta perubahan yang ada agar mampu bersaing dalam bisnis kuliner yang ada saat ini.

Dengan semakin majunya teknologi, maka tinggi keinginan konsumen untuk mendapatkan suatu produk yang lebih baik, hal ini akan membuat Perusahaan bersaing untuk memenuhi kebutuhan pelanggannya. Hal ini menciptakan persaingan dalam dunia bisnis. Dalam upaya memenangkan persaingannya setiap Perusahaan harus mampu mengenal apa yang menjadi kebutuhan dan harapan konsumen saat ini maupun yang akan datang, konsumen sebagai individu dalam mendapatkan atau membeli barang telah melalui proses-proses atau tahapantahapan terlebih dahulu seperti mendapatkan informasi baik melalui iklan atau referensi dari orang lain kemudian membandingkan produk itu dengan produk yang lain sampai akhirnya pada keputusan membeli suatu produk itu. Perilaku konsumen merupakan fenomena yang sangat penting dalam kegiatan pemasaran Perusahaan, yaitu perilaku konsumen dalam melakukan pembelian. Demikian juga halnya kualitas merupakan salah satu faktor yang menjadi pertimbangan konsumen sebelum membeli suatu produk. Dengan kualitas yang bagus dan terpercaya, maka 
produk akan senantiasa tertanam dibenak konsumen, karena konsumen bersedia membayar sejumlah uang untuk membeli produk yang berkualitas.

\section{Hipotesis dan Tujuan Penelitian}

Hipotesis dalam penelitian ini adalah :

1. Adanya pengaruh kualitas produk terhadap keputusan pembelian pada Restoran A\&W Supermall Karawaci?

2. Adanya pengaruh harga terhadap keputusan pembelian pada Restoran $A \& W$ Supermall Karawaci?

3. Bagaimana pengaruh kualitas produk dan harga terhadap keputusan pembelian pada Restoran A\&W Supermall Karawaci?

Adapun tujuan penelitian yang hendak dicapai dalam penelitian ini adalah:

1. Untuk mengetahui seberapa besar pengaruh kualitas produk terhadap keputusan pembelian di Restoran A\&W Supermall Karawaci ?

2. Untuk mengetahui seberapa besar pengaruh harga terhadap keputusan pembelian di Restoran A\&W Supermall Karawaci?

3. Untuk mengetahui seberapa besar pengaruh antara kualitas produk dan penentuan harga pada keputusan pembelian di Restoran A\&W Supermall Karawaci?

\section{Metode Penelitian}

Dalam penelitian ini penulis menggunakan metode deskriptif kuantitatif. Model penelitian deskriptif adalah untuk membuat deskripsi atau gambaran secara sistematis dan akurat sifat-sifat yang berhubungan antara fenomena yang akan diteliti. Dalam melakukan penelitian mengenai masalah yang akan dibahas, metode yang dipilih adalah metode penelitian survei dari setiap responden melalui kuesioner. dalam penelitian ini, penulis akan mengambil sampel sebanyak 100 responden yang merupakan konsumen dari Restoran A\&W Supermall Karawaci. Sesuai dengan judul penelitian yaitu Pengaruh Kualitas Produk dan Harga terhadap Keputusan Pembelian pada Restoran A\&W, maka dalam penelitian ini terdapat 3 (tiga) variabel yang digunakan, yaitu variabel kualitas produk (X1), variabel harga (X2), dan variabel keputusan pembelian (Y).

\section{Analisa dan Pembahasan}

\section{Uji Validitas dan Reliabilitas Variabel Citra Perusahaan (X1)}

Untuk mengetahui ada atau tidaknya pengaruh antara variabel X1 (Kualitas Produk), X2 (Harga), Y (Keputusan Pembelian) serta mengukur kuat atau tidaknya pengaruh tersebut, maka digunakan reabilitas dengan menggunakan perhitungan SPSS. Dalam penellitian ini penulis membuat 10 pernyataan tentang kualitas produk. Untuk mengetahui apakah semua pertanyaan tersebut realibel, maka digunakan uji reabilitas dengan hasil terlihat bahwa nilai cronbach Alpha adalah sebesar 0,953 dengan jumlah pernyataan 10. Jika dibandingkan dengan nilai Cronbach Alpha menurut Stanisiess S. Uyanto dalam bukunya pedoman analisis Data dengan SPSS $(2010,274)$ Cronbach Alpha minimal yang cukup kuat dapat diterima (acceptable) adalah yang bernilai 0,70 atau lebih. Sedangkan nilai Cronbach Alpha 
yang didapatkan adalah 0.953 yang artinya sudah melebihi nilai standar reliabel. Nilai Cronbach Alpha dari variabel kualitas produk lebih dari nilai a $=0,70$ Jadi semua kusioner tentang kualitas produk tersebut terbukti reliabel. Tabel item-total statistik menunjukan hasil perhitungan reabilitas untuk 10 pernyataan.Menentukan besarnya $r$ tabel dengan ketentuan tingkat kepercayaan (degree of freedom=df) jumlah responden-2 atau 100-2 = 98 maka tingkat signifikan 5\%, maka nilai $\mathrm{r}$ dari tabel sebesar 0,195.Membandingkan $r$ tabel dengan setiap $r$ pertanyaan, dengan cara membandingkan output corrected item-total correlation dengan 0,195 ( $\mathrm{r}$ tabel) Jika dibandingkan dengan $\mathrm{r}$ tabel pada tabel correlated item-total correlation, nilai $\mathrm{r}$ hitung semua pertanyaan tentang kualitas produk lebih besar dari $\mathrm{r}$ tabel, artinya semua pertanyaan valid.

\section{Uji Validitas dan Reliabilitas Variabel Harga (X2)}

Dalam penelitian ini penulis membuat 10 pernyataan tentang harga Untuk mengetahui apakah semua pernyataan tersebut realibel, maka digunakan uji reabilitas dengan hasil. Pada tabel 4.39 reability statistic diatas terlihat bahwa nilai Cronbach Alpha adalah sebesar 0,948 dengan jumlah pernyataan 10. Jika dibandingkan dengan nilai Cronbach Alpha menurut Stanisless S. Uyanto dalam bukunya pedoman analisis Data dengan SPSS $(2010,274)$ Cronbach Alpha minimal yang cukup dapat diterima (acceptable) adalah yang bernilai 0,70 atau lebih. Sedangkan nilai Cronbach Alpha yang didapatkan adalah 0.948 yang artinya melebihi standar reliabel. Nilai Cronbach Alpha dari variabel harga lebih dari a=0,70. Jika semua kuisioner tentang harga tersebut terbukti reliabel. Tabel item-total statistik menunjukan hasil perhitungan reabilitas untuk 10 pernyataan. Menunjukan besarnya $\mathrm{r}$ tabel dengan ketentuan tingkat kepercayaan (degree of freedom-df) jumlah responden 100-2 = 98 dengan tingkat signifikan 5\%, maka nilai $\mathrm{r}$ dari tabel sebesar 0,195. Membandingkan $r$ tabel dengan setiap $r$ pernyataan, dengan cara membandingkan output corrected item-total-total correlation dengan 0,195 ( $\mathrm{r}$ tabel). Jika dibandingkan dengan $\mathrm{r}$ tabel pada tabel correlated item-total correlation, maka nilai $r$ hitung semua pernyataan tentang harga lebih besar dari $r$ tabel, artinya semua pernyataan sudah valid.

\section{Uji Validitas dan Reliabilitas Variabel Keputusan Pembelian Konsumen (Y)}

Dalam penelitian ini penulis memberikan 10 pernyataan tentang keputusan pembelian konsumen. Untuk mengetahui apakah semua pernyataan tersebut reliabel, maka dilakukan uji reabilitas dengan hasil Pada tabel reabilty statistic diatas terlihat bahwa nilai cronbach Alpha adalah sebesar 0,771 dengan jumlah pernyataan 10. Jika dibandingkan dengan nilai Cronbach Alpha menurut Stanisless S.Uyanto dalam bukunya pedoman analisis data dengan SPSS (2010:274) Cronbach Alpha minimal yang cukup diterima (acceptable) adalah yang bernilai antara 0,70 atau lebih. Sedangkan nilai Cronbach Alpha yang didapatkan adalah 0,967 yang artinya sudah melebihi standar reliabel.

Nilai cronbach Alpha dari variabel keputusan pembelian konsumen lebih dari nilai $a=0,70$. Jika semua kusioner tentang keputusan pembelian konsumen tersebut terbukti reliabel. Tabel item-total statistic menunjukan hasil perhitungan reabilitas untuk 10 pernyataan. Menentukan besarnya $\mathrm{r}$ tabel dengan ketentuan tingkat kepercayaan (degree of freedom $=\mathrm{df}$ ) jumlah responden-2 atau 100-2=98 dengan tingkat signifikan 5\%, maka nilai $\mathrm{r}$ dari tabel sebesar 0,195. Membandingkan tabel 
dengan setiap r pernyataan, dengan cara membandingkan output corrected item-total correlation dengan 0,195 ( $\mathrm{r}$ tabel). Jika dibandingkan dengan $\mathrm{r}$ tabel pada tabel correlated item-total correlation, nilai $\mathrm{r}$ hitung semua pernyataan tentang keputusan pembelian konsumen lebih besar dari $\mathrm{r}$ tabel, artinya semua pertanyaan valid.

\section{Correlations}

\begin{tabular}{|c|c|c|c|c|}
\hline & & $\begin{array}{c}\text { Keputus } \\
\text { an } \\
\text { Pembelia } \\
n\end{array}$ & $\begin{array}{l}\text { Kualitas } \\
\text { Produk }\end{array}$ & Harga \\
\hline \multirow[t]{3}{*}{$\begin{array}{l}\text { Pearson } \\
\text { Correlation }\end{array}$} & $\begin{array}{l}\text { Keputusan } \\
\text { Pembelian }\end{array}$ & 1,000 & 871 & 866 \\
\hline & Kualitas Produk & 871 & 1,000 & 882 \\
\hline & Harga & ,866 & ,882 & 1,000 \\
\hline \multirow[t]{3}{*}{ Sig. (1-tailed) } & $\begin{array}{l}\text { Keputusan } \\
\text { Pembelian }\end{array}$ & & ,000 & ,000 \\
\hline & Kualitas Produk & 000 & & ,000 \\
\hline & Harga & ,000 & ,000 & \\
\hline \multirow[t]{3}{*}{$\mathrm{N}$} & $\begin{array}{l}\text { Keputusan } \\
\text { Pembelian }\end{array}$ & 100 & 100 & 100 \\
\hline & Kualitas Produk & 100 & 100 & 100 \\
\hline & Harga & 100 & 100 & 100 \\
\hline
\end{tabular}

Sumber : Data SPSS 22.00

Dari tabel diatas dapat dilihat bahwa :

Besar hubungan Kualitas Produk ditunjukan dengan nilai koefisien korelasi sebesar 0.871 mendekati 1. Besar pengaruh harga ditunjukan dengan nilai koefisien korelasi sebesar 0.866 mendekati 1, maka hubungan Kualitas Produk dan Harga terhadap keputusan pembelian pada Restoran A\&W Supermall Karwaci adalah kuat dan mempunyai hubungan yang positif. Tabel Correlation menunjukan bahwa antara kualitas produk dan harga sangat signifikan atau tidak dengan peningkatan keputusan pembelian konsumen, dapat dilihat dari angka-angka sebesar $0.000<0,05$ menunjukan hasil korelasi ketiga variabel adalah signifikan artinya menolak Ho dan menerima Ha. Pada kolom $t$ digunakan pengujian $t$ untuk menguji kebenaran dari hipotesis yang ada, dilakukan dengan cara membandingkan nilai t hitung yang telah diperoleh dengan nilai tabel. Kriteria pengujian: Jika thitung > $t$ tabel maka Ho ditolak dan Ha diterima, Jika $t$ hitung < $\mathrm{t}$ tabel maka Ho diterima dan Ha ditolak.

Pada kolom $t$ diketahui bahwa $t$ hitung untuk kualitas produk (X1) adalah sebesar 2.454 dengan menggunakan tabel distribusi normal $t$ dan menggunakan tingkat keyakinan pengujian (1- a) sebesar 95\% dan tingkat kesalahan (a) $n-2=100-2=98$, maka diperoleh nilai distribusi tabel $t$ adalah 1.984 . oleh karena $t$ hitung harga lebih besar dari nilai tabel atau $2.454>1.660$, maka Ho ditolak dan Ha diterima. Sedangkan kolom $t$ hitung untuk harga (X2) adalah sebesar 3.801 dengan menggunakan tabel distrbusi normal $\mathrm{t}$ dan menggunakan tingkat kesalahan (a) sebesar $5 \%$ serta derajat kebebasan (Degree Of Freedom) atau (df) n $-2=100-2=98$, 
maka diperoleh nilai distribusi tabel $t$ adalah 1.660. oleh karena itu $t$ hitung harga lebih besar dari tabel $\mathrm{t}$ atau 3.801 > 1.984, maka Ho ditolak dan Ha diterima. Pada kolom signifikan digunakan untuk pengujian probalitas. Kriteria pengujian: Jika Probalitas > 0.05 maka Ho ditolak dan Ha diterima, jika Probalitas < 0.05 maka Ho diterima dan Ha ditolak.

ANOVA ${ }^{\mathrm{a}}$

\begin{tabular}{|c|c|c|c|c|c|}
\hline Model & $\begin{array}{l}\text { Sum of } \\
\text { Squares }\end{array}$ & Df & $\begin{array}{l}\text { Mean } \\
\text { Square }\end{array}$ & $\mathrm{F}$ & Sig. \\
\hline $\begin{array}{ll}1 & \begin{array}{l}\text { Regressi } \\
\text { on }\end{array}\end{array}$ & 5069,566 & 1 & 5069,566 & 308,095 &, $000^{\mathrm{b}}$ \\
\hline Residual & 1612,544 & 98 & 16,455 & & \\
\hline Total & 6682,110 & 99 & & & \\
\hline \begin{tabular}{|ll}
2 & $\begin{array}{l}\text { Regressi } \\
\text { on }\end{array}$
\end{tabular} & 5358,080 & 2 & 2679,040 & 196,270 &, $000^{\circ}$ \\
\hline Residual & 1324,030 & 97 & 13,650 & & \\
\hline Total & 6682,110 & 99 & & & \\
\hline
\end{tabular}

a. Dependent Variable: Keputusan Pembelian

b. Predictors: (Constant), Kualitas Produk

c. Predictors: (Constant), Kualitas Produk, Harga

Sumber : Data SPSS 22.00

Dari uji ANOVA didapat $F_{\text {Hitung }}$ untuk model 1 adalah 308.095 dengan tingkat signifikan 0.000 dimana angka $0.000<0.05$ dan juga $F$ Hitung > $F$ tabel atau 308.095> 2.46 ,dengan demikian Ho ditolak dan Ha diterima artinya terdapat pengaruh linear antara korelasi harga dengan keputusan pembelian, maka model regresi tersebut sudah layak dan tepat untuk memprediksi keputusan pembelian.

Dari uji ANOVA didapat $\mathrm{F}$ Hitung untuk model 2 adalah 196.270 dengan tingkat signifikan $0.000<0.05$ dan juga $\mathrm{F}$ Hitung $>\mathrm{F}$ tabel atau $196.270>2.46$, dengan demikian Ho ditolak dan Ha diterima artinya terdapat pengaruh linear antara korelasi harga dan kualitas produk dengan keputusan pembelian, maka model regresi tersebut sudah layak dan tepat untuk memprediksi keputusan pembelian konsumen.

Model Summary

\begin{tabular}{|c|c|c|c|c|c|c|}
\hline \multirow[b]{2}{*}{ Model } & \multirow[b]{2}{*}{$\mathrm{R}$} & \multirow[b]{2}{*}{ R Square } & \multirow[b]{2}{*}{$\begin{array}{l}\text { Adjusted } \\
\text { R Square }\end{array}$} & \multirow{2}{*}{$\begin{array}{c}\text { Std. } \\
\text { Error of } \\
\text { the } \\
\text { Estimat } \\
\text { e }\end{array}$} & \multicolumn{2}{|c|}{ Change Statistics } \\
\hline & & & & & $\begin{array}{c}\mathrm{R} \\
\text { Square } \\
\text { Chang } \\
\mathrm{e}\end{array}$ & $\begin{array}{c}\mathrm{F} \\
\text { Change }\end{array}$ \\
\hline 1 & $871^{a}$ & 759 & ,756 & 4,056 & ,759 & 308,095 \\
\hline 2 & $895^{b}$ & ,802 & ,798 & 3,695 & ,043 & 21,137 \\
\hline
\end{tabular}

\section{Coefficients ${ }^{a}$}




\begin{tabular}{|c|c|c|c|c|c|c|}
\hline \multirow{2}{*}{\multicolumn{2}{|c|}{ Model }} & \multicolumn{2}{|c|}{$\begin{array}{c}\text { Unstandardized } \\
\text { Coefficients }\end{array}$} & \multirow{2}{*}{\begin{tabular}{|c|}
$\begin{array}{c}\text { Standardized } \\
\text { Coefficients }\end{array}$ \\
Beta \\
\end{tabular}} & \multirow[b]{2}{*}{$\mathrm{t}$} & \multirow[b]{2}{*}{ Sig. } \\
\hline & & B & $\begin{array}{l}\text { Std. } \\
\text { Error }\end{array}$ & & & \\
\hline & (Constant) & 6,241 & 1,947 & & 3,205 & ,002 \\
\hline & $\begin{array}{l}\text { Kualitas } \\
\text { Produk }\end{array}$ & 895 & ,051 & 871 & 17,553 & ,000 \\
\hline \multirow[t]{3}{*}{2} & (Constant) & 3,116 & 1,899 & & 1,640 & ,104 \\
\hline & $\begin{array}{l}\text { Kualitas } \\
\text { Produk }\end{array}$ & ,495 & ,099 & , 482 & 5,023 & ,000 \\
\hline & Harga & ,485 & 106 & ,441 & 4,597 & ,000 \\
\hline
\end{tabular}

Sumber : Data SPSS 22.00

Dari perhitungan koefisien korelasi pada tabel 4.46, nilai koefisien korelasi (R) antara variabel independen kualitas Produk $\left(\mathrm{X}_{1}\right)$, dengan variabel dependen keputusan pembelian konsumen $Y$ dengan nilai sebesar 0,871. Karena nilainya tersebut hampir mendekati 1, maka antara variabel independen Kualitas Produk $X_{1}$ dengan variabel dependen keputusan pembelian konsumen $\mathrm{Y}$ mempunyai hubungan kuat atau sempurna. Jadi koefisien determinasi diperoleh nilia $\mathrm{R}^{2}$ sebesar $0.871 \times 0.871=0.759$. Berarti hal ini menunjukkan bahwa variabel independen Kualitas Produk $X_{1}$ dengan variabel dependen keputusan pembelian Y mempunyai pengaruh sebesar $75,9 \%$ dan sisanya sebesar $24,1 \%$ dipengaruhi oleh faktor yang lainnya.

Dari perhitungan koefisien korelasi pada tabel di atas, nilai koefisien korelasi (R) antara variabel independen Kualitas Produk $\left(\mathrm{X}_{1}\right)$, dengan variabel dependen keputusan pembelian $(\mathrm{Y})$ dengan nilai sebesar 0,895. Karena nilainya tersebut hampir mendekati 1, maka antara variabel independen kualitas produk $X_{1}$ dengan variabel dependen keputusan pembelian (Y) mempunyai hubungan kuat atau sempurna. Jadi koefisien determinasi diperoleh nilia $\mathrm{R}^{2}$ sebesar $0.895 \times 0.895=0.802$. Berarti hal ini menunjukkan bahwa variabel independen Kualitas Produk $X_{1}$ dan Harga dengan variabel dependen keputusan pembelian $(\mathrm{Y})$ mempunyai pengaruh sebesar $80,2 \%$ dan sisanya sebesar 19,8\% dipengaruhi oleh faktor yang lainnya.

\section{Uji t}

Untuk mengetahui apakah masing-masing variabel Kualitas Produk (X1), Harga (X2) secara parsial mempunyai hubungan bermakna terhadap keputusan Pembelian (Y) dilakukan pengujian thitung dan tabel. Uji $t$ ini dilakukan dengan cara membandingkan antara hasil thitung dengan ttabel yaitu memiliki nilai masing-masing sebagai berikut : 
Hasil Uji t

\begin{tabular}{|l|c|c|c|}
\hline \multicolumn{1}{|c|}{ Variabel } & $\begin{array}{c}\text { Standard } \\
\text { Error }\end{array}$ & T Hitung & T Tabel \\
\hline Kualitas Produk $(\mathrm{X} 1)$ & 0,095 & 5.023 & 1,660 \\
\hline Harga $(\mathrm{X} 2)$ & 0,095 & 4,597 & 1,660 \\
\hline
\end{tabular}

Atas dasar uji $\mathrm{t}$ tersebut di atas, terbukti bahwa variabel Kualitas Produk $\left(\mathrm{X}_{1}\right)$, Ksecara parsial mempunyai pengaruh terhadap keputusan pembelian (Y) pada tarap nyata. Dengan demikian dapat dinyatakan bahwa $\mathrm{H}_{0}$ ditolak $\mathrm{H}_{1}$ diterima.

Dari hasil uji hipotesis antara Kualitas Produk $\left(\mathrm{X}_{1}\right)$ dengan keputusan pembelian konsumen (Y) diperoleh yakni karena nilai $t_{o}=5.023>t_{0,05}(98)=1,660$, maka $H_{o}$ ditolak dan $\mathrm{H}_{\mathrm{a}}$ diterima dengan taraf nyata (signifikan level) sebesar 95\% yang berarti mempunyai cukup bukti bahwa antara variabel Kualitas Produk $\left(\mathrm{X}_{1}\right)$ dengan keputusan pembelian (Y) ada hubungan kuat. Dari hasil uji hipotesis variabel Harga $\left(X_{2}\right)$ dengan keputusan pembelian $(Y)$ diperoleh yakni karena nilai $t_{o}=4.597>t_{0,05}$ $(98)=1,660$, maka $\mathrm{H}_{\mathrm{o}}$ ditolak dan $\mathrm{H}_{\mathrm{a}}$ diterima dengan taraf nyata (signifikan level) sebesar $95 \%$ yang berarti mempunyai cukup bukti bahwa antara variabel Harga $\left(X_{2}\right)$ dengan keputusan pembelian (Y) ada hubungan yang kuat.

\section{Kesimpulan}

1. Dari hasil penelitian terhadap pengaruh kualitas produk (X1) dan harga $(X 2)$ terhadap keputusan pembelian $(Y)$ pada Restoran $A \& W$ adalah dengan menggunakan analisa koefisien korelasi yang diketahui bahwa pengaruh kualitas produk dan harga memiliki pengaruh yang positif dalam keputusan pembelian. Koefisien korelasi adalah sebesar 0,871 untuk kualitas produk (X1) dan 0,866 untuk harga (X2) yang berarti memiliki pengaruh yang positif.

2. $\mathrm{R}$ square (R2) menunjukan koefisien determinasi yang artinya presentase sumbangan pengaruh variabel independen terhadap dependen. Nilai R2 variabel kualitas produk terhadap keputusan pembelian adalah 75,9\% sedangkan sisanya $24,1 \%$ dipengaruhi oleh faktor-faktor lain. Jika dilakukan pengujian secara bersama-sama besarnya nilai R2 variabel kualitas produk dan harga terhadap keputusan pembelian adalah $80.2 \%$, sedangkan sisanya $19.8 \%$ dipengaruhi oleh faktor lain.

3. Berdasarkan hasil uji $\mathrm{F}$ untuk variabel kualitas produk dan harga terhadap keputusan pembelian, didapatkan nilai $\mathrm{f}$ hitung $>\mathrm{f}$ tabel, maka Ho ditolak dan Ha diterima artinya terdapat pengaruh yang signifikan dari kualitas produk dan harga terhadap keputusan pembelian atau model yang digunakan layak untuk menjelaskan pengaruh variabel kualitas produk (X1) dan harga (X2) terhadap keputusan pembelian $(\mathrm{Y})$.

4. Berdasarkan hasil uji hipotesis untuk variabel kualitas produk maka diperoleh hasil $\mathrm{t}$ hitung sebesar 5.023 dan uji hipotesis untuk variabel harga maka diperoleh hasil $\mathrm{t}$ hitung sebesar 4.597 dan uji $\mathrm{t}$ tabel sebesar 1.660, sehingga dapat diambil kesimpulan $\mathrm{t}$ hitung $>\mathrm{t}$ tabel yang berarti Ho ditolak dan Ha diterima. Hal ini menunjukan bahwa terdapat pengaruh cukup kuat antara kualitas produk dan harga terhadap keputusan pembelian.

5. Dari hasil penelitian yang telah dilakukan didapatkan rumus regresi berganda: $\mathrm{Y}=3.116+0,495 \mathrm{X} 1+0,485 \mathrm{X} 2$ 


\section{Daftar Pustaka}

Anogara,Panji. (2011). Pengantar Bisnis. Jakarta: Rineka Cipta

Buchari, Alma, (2013). Manajemen Pemasaran dan Pemasaran Jasa. Bandung: Alfabeta.

Daryanto. (2011). Sari Kuliah Manajemen Pemasaran. Bandung: PT Sarana Tutorial Nurani Sejahtera.

Griffin dan Elbert. (2012). Pengantar Bisnis. PT.Indeks.Jakarta

Kotler, Philip and Kevin Lan Keller (2011). Manajemen Pemasaran. Jakarta: Erlangga Manullang. (2012). Dasar-Dasar Manajemen. Yogyakarta: Gajah Mada University Press.

Oentoro, Deliyanti. (2012). Manajemen Pemasaran Modern. Yogyakarta: Laksbang Pressindo.

Ririn Tri Ratnasari dan Mastuti H. Aksa. (2011). Manajemen Pemasaran Jasa. Bogor: Ghalia Indonesia.

Saladin, Djaslim (2015). Manajemen Strategi Pemasaran. Bandung: Linda Karya

Sugiyono. (2011). Metode Penelitian Kuantitatif, Kualitatif dan R\&D. Bandung:Alfabeta

Sunarto. (2011). Manajemen Pemasaran. Yogyakarta: Aditya Media

Sunyoto, Danang. (2012). Dasar-Dasar Manajemen Pemasaran. Yogyakarta: CAPS.

Tjiptono, Fandy dan Gregorius Chandra. (2012). Pemasaran Strategik. Yogyakarta:

C. V Andy Offset

Wijaya, Tony. (2011).Manajemen Kualitas Jasa. Jakarta: Indeks.

Basu Swasta dan Hani Handoko. (2010). Manajemen Pemasaran: Analisa dan perilaku Konsumen. BPFE, Yogyakarta

Kotler dan Keller. (2012). Marketing Management, 14th. Person Education

Yamit,Zulian. (2011). Manajemen Kualitas Produk dan Jasa. Ekonisia, Yogyakarta.

Daryanto. (2012). Pendidikan Kewirausahaan. Gava Media: Jakarta. 